\title{
MENGAJAR MENGAJI DI TPA/TPQ AR-RAHMAN
}

\section{INDAH}

NIM: 9173770410290

Email: ndahbakwan07@gmail.com

\section{Bentuk Kegiatan}

Mengajar mengaji Al Qur'an.di TPA/TPQ Ar-Rahman

\section{Lokasi}

Desa Balangloe Tarowang,Dusun Balangloe Tarowang di TPA/TPQ Ar-Rahman

\section{Hari/Tanggal dan Waktu}

Pada hari Senin tanggal 28 september 2020

Jam 16:00

\section{Peserta yang Dilibatkan}

Peserta KKLP, Anak TPA/TPQ

Dan Bebera ustadz/ustadza

\section{Alasan Diadakannya}

Agar anak-anak bisa lebih paham tentang huruf-huruf hijayyah dan lebih faham tentang arti dan makna

\section{Tujuan dan Manfaat}

- Tujuan Agar peserta didik menjadi generasi Qur'an yang mencintai Al-Qur'an dan menjadikan Al-Qur'an sebagai bacaan dan pandangan hidup sehari-hari.

- Manfaat Menjadi bekal untuk menghadapi hari akhir,mendapatkan pahala yang berlipat ganda dan dikumpulkan bersama para malaikat.

\section{Produk Kegiatan (Jika Ada)} Yaitu. Al-Qur'an dan Iqro.

\section{Deskripsi Kegiatan}

Adalah proses perubahan tingkah laku peserta didik melalui proses belajar mengajar,membimbing,dan melatih peserta didik untuk membaca Al-Qur'an dengan fasi dan benar sesuai kaidah ilmu tajwid agar peserta didik terbiasa belajar membaca Al-Qur'an dalam kehidupan sehari-hari

\section{Referensi Wajib}

- HERIANTO, H., \& Amir, A. S. (2020, September 10). Pedoman Pelaksanaan Kuliah Kerja Lapangan Plus (KKLP) Mahasiswa STIE dan STKIP YAPTI Jeneponto. https://doi.org/10.31219/osf.io/7dvpk 
